\title{
Evaluation of the Performance of an Activated Carbon Supplemented Sand Filter for the Reduction of COD in Brewery Wastewater
}

\author{
Elvis Fosso-Kankeu, Chane van den Heever, Gerhard Gericke, Nico Lemmer, Frans Waanders
}

\begin{abstract}
Water scarcity being a global challenge experienced strongly in South Africa, the treatment of wastewater for reuse is becoming top priority. The scarcity of water is exacerbated by pollution from industrial effluents. It is estimated that for the production of $1 \mathrm{~L}$ of beer approximately $10 \mathrm{~L}$ of waste effluent is produced. As a result opaque beer brewing industries discharge large volumes of acidic and highly polluting effluents. To treat such effluents a combination of coagulation/flocculation and sand filter has been considered in this study. The sand filter was engineered using different types of activated carbons to enhance its performance. The results obtained showed that the presence of activated carbons in the filter bed significantly contribute to the reduction of turbidity and COD from the wastewater.
\end{abstract}

Index Terms-Activated carbon, Brewery wastewater, Chemical oxygen demand (COD), Filtration

\section{INTRODUCTION}

Pollution of surface water by industrial effluents is a serious concern in South Africa where mining activities are reported to contribute to significant discharge of inorganic pollutants in the environment $[1-10]$. There is also an increasing amount of organic pollutants found in the surface water, which may derive from brewing processes that produce large volumes of wastewater disposed in the environment.

Sorghum beer is produced from sorghum grits, sorghum malt, water and yeast, with water often referred to as the main ingredient as it is used in multiple stages of the brewing process. During malting, sorghum grains undergo steeping, germination and kilning. According to Steffen et al. [11] the malt undergoes milling and results in an effluent that has a low $\mathrm{pH}$ as well as a high concentration of organic compounds [12]. Mashing and filtering follow and the yeast is added to initiate fermentation. Cleaning of the process equipment contributes largely to the amount of effluent generated and is a major source of contaminants [13].

Manuscript received August 29, 2017. This work was supported in part by the National Research Foundation in South Africa (NRF) and Eskom. Any opinion, findings and conclusions or recommendations expressed in this material are those of the authors and therefore the NRF does not accept any liability in regard thereto.

Elvis Fosso-Kankeu is with the School of Chemical and Minerals

Engineering of the North West University, Bult area-Potchefstroom-South Africa

Frans Waanders is with the School of Chemical and Minerals

Engineering of the North West University, Bult area-Potchefstroom-South

Africa

Chane van den Heever is with the School of Chemical and Minerals

Engineering of the North West University, Bult area-Potchefstroom-South.
Brewery wastewater is contaminated with an abundance of organic and inorganic chemical species. For the purpose of this study the $\mathrm{pH}$ level, COD content and turbidity of the effluent were measured and analysed in accordance with standard methods. Brewery effluent may range from $\mathrm{pH} 2-$ 10 with a suspended solids concentration of up to $2500 \mathrm{mg} / \mathrm{L}$ and COD levels reaching $6000 \mathrm{mg} / \mathrm{l} \mathrm{[14].} \mathrm{Oxygen} \mathrm{in} \mathrm{water} \mathrm{is}$ needed for bacterial activity to take place. The used oxygen is restored through aeration when the water is mixed [15]. Therefore, if the dissolved oxygen is used more rapidly than it can be replaced, a decrease in bacterial activity is observed and may lead to the death of bacteria as a whole.

Turbidity is a result of dissolved or suspended substances such as microorganisms, organic and inorganic materials, algae etc. and as a result the water appears cloudy or murky. Apart from the aesthetic quality of the water decreasing with an excess of turbidity, aquatic life could also be under threat [16].

Therefore the effluent generated by such breweries requires certain treatment methods. Due to the high adsorption capability of activated carbon, it is often used to improve contaminant removal. The coagulation and flocculation processes are important components of wastewater treatment $[17-21]$. Due to the extreme pH and turbidity levels, Ferric Chloride will be used during the coagulation and flocculation stages of this study.

Granular multimedia filter consists of silica sand, anthracite and activated carbon. Anthracite coal is a hard and brittle coal with an exceptionally high carbon content and very little volatile matter [22]. Anthracite can remove residual hardness salts and various other solids due to its ability to facilitate the adsorption and flocculation of colloidal particles onto its surface. Therefore, if used appropriately in a granular filter, anthracite can reduce effluent turbidity and suspended solids content. Granular activated carbon (GAC) is used as a filter media because of its known ability to adsorb organic compounds that are found in the wastewater. Due to the intermolecular attractions of the GAC and its highly porous structure, organic compounds can adhere to the surface of the granules because of the strong adsorption forces that occur [23].

The use of a multimedia granular filter is a cost effective way to lower a brewery's impact on the environment. This paper aims to determine the effectiveness of COD removal from brewery wastewater using a sand filter engineered with activated carbon. 


\section{MATERIALS AND PROCEDURE}

\section{A. Sampling and Preparation}

Wastewater was sampled at the discharge point of the water treatment plant of United National Breweries' Tlokwe Brewery in Potchefstroom, South Africa. In order to ensure consistent and trustworthy results, all sampling were done after the cleaning process at 11:00 am during the week. The sampled wastewater was retrieved in $25 \mathrm{~L}$ plastic containers and moved to the filter test plant used during the study. The brewery effluent was allowed to settle 1-2 hours in a dark space before preparation commenced. Testing was done as soon as possible after the sampling to ensure the water remained unchanged. During this time the wastewater was monitored and analysed in accordance with standard methods and the parameters measured included $\mathrm{pH}$, turbidity and chemical oxygen demand (COD).

\section{B. Coagulation \& Flocculation}

Ferric Chloride was used as a coagulant because of its ability to work over a wide $\mathrm{pH}$ range (4-11). Also, due to the relatively low formula weight of ferric chloride, if compared to other flocculants such as alum, it should form a heavy floc. Therefore ferric chloride can promote settling [24].

Using standard procedures, simple jar tests were conducted. $2.42 \mathrm{~g}$ Ferric chloride hexahydrate $\left(5 \mathrm{mg} \mathrm{Fe} 3^{3^{+}} /\right.$ $\mathrm{ml}$ ) were dissolved in $100 \mathrm{~mL}$ of distilled water to form the ferric chloride dilution that was used during coagulation.

Well mixed wastewater $(200 \mathrm{~mL})$ was measured into one of six beakers in which various doses of Ferric Chloride solution were added at a later stage. Rapid mixing at $200 \mathrm{rpm}$ was performed for $1 \mathrm{~min} 30 \mathrm{sec}( \pm 20 \mathrm{sec})$, followed by slow mixing at $60 \mathrm{rpm}$ for $15 \mathrm{~min}$. Hereafter the effluent was allowed to settle for $40 \mathrm{~min}$. The results obtained are recorded in Table 1. Dosages of 15-20 mL Ferric Chloride solution to 1 $\mathrm{L}$ of wastewater resulted in optimum turbidity removal. The optimum dosage of $15 \mathrm{~mL}$ ferric chloride added to $1 \mathrm{~L}$ of wastewater was used in all experimentations.

\section{Granular multimedia filter}

Transparent PVC pipes were cut to have a height of $100 \mathrm{~cm}$ and an internal diameter of $9.3 \mathrm{~cm}$. Sampling points were added to the filter at various heights.

After coagulation and sedimentation, it was discharged from a funnel shaped container at an elevated height through a pipe. The elevation of the settling tanks allows the water to be passed through the filter at a high pressure. A make-shift showerhead at the top of the filter, allows for even water distribution and therefore minimising channelling in the media.

The proposed granular multi-media filter consisted of layers of sand, anthracite and activated carbon and was connected to the settled water tanks in a laboratory scale water treatment plant (LSWTP). Media in the filter was arranged in accordance to media density: Anthracite is less dense than sand and thus a $25 \mathrm{~cm}$ layer of anthracite was placed on top of the sand in the column, the activated carbon was placed as a thin layer $(10 \mathrm{~cm})$ in the sand layer at approximately $30 \mathrm{~cm}$ from the bottom of the filter, and a combined column height of $75 \mathrm{~cm}$ was achieved.
Four different activated carbon samples were characterised and used respectively in the filters, the results were compared and analysed in order to establish the potential of the different activated carbons for COD and turbidity removal.

\section{Measurements}

Throughout experimentation the parameters that were measured included: Temperature, $\mathrm{pH}$, Turbidity and COD. Measurements were taken after sampling at the source using $\mathrm{pH}$ combined electrode with integrated temperature probe and COD and Multiparameter Bench Photometer HI 83099 (Hanna Instruments Inc., U.S.A.) respectively [25 - 29], after coagulation and flocculation as well as at the various sampling point of the filter and were used as indicators of the effectiveness of the various components and media used.

It was expected that the levels of COD and turbidity of the water will decrease after passing the feed water through the filter.

\section{RESULTS \& DISCUSSION}

Water treatment involves various processes and is necessary in order to comply with water quality standards. Traditional water treatment schemes involve coagulation, flocculation, and sedimentation, followed by filtration. Coagulation and flocculation is the process where suspended solids are aggregated to form larger flocs [30 - 34]. The force of gravity then allows these flocs to settle, resulting in clear water on top. Hereafter the water is passed through a filter comprised of media such as silica sand, completing the treatment process. In the case of drinking water production, additional treatment stages such as ozonation, chlorination and/or fluorination are necessary to ensure proper disinfection. This section addresses the results related to the performance of filters and filter media used.

Filters were loaded with silica sand, anthracite and a layer of activated carbon. After settling of flocs, the clear water was separated from the sediment and added to the filters. The effect of four different activated carbon samples was analysed by loading each filter with a different activated carbon. A filter loaded only with anthracite and sand was used as a base to determine the effect of the addition of activated carbon in filters. The $\mathrm{pH}$ level, turbidity and COD of the water in the filters were determined in order to assess the performance of each filter. All filters were loaded at the same rate and the same amount of water was added to each filter.

\section{A. Turbidity}

Turbidity is widely used as a quality control measure for determining the efficiency of water treatment systems. An excess of suspended solids indicates high levels of bacteria, contaminants and pathogens, and could block light from reaching aquatic plants. Therefore water is treated to adhere to specific standards ensuring safe discharge. The effectiveness of filters can be assessed by measuring turbidity removal in the water.

The sampled water had high turbidity levels of 2000 NTU before coagulation. The filters were run as a two part tests, firstly activated carbon one and two were compared, part 2 was conducted accordingly using activated carbon three and four. Figure 1 to Figure represent the turbidity values at each sampling point of the various filters. 


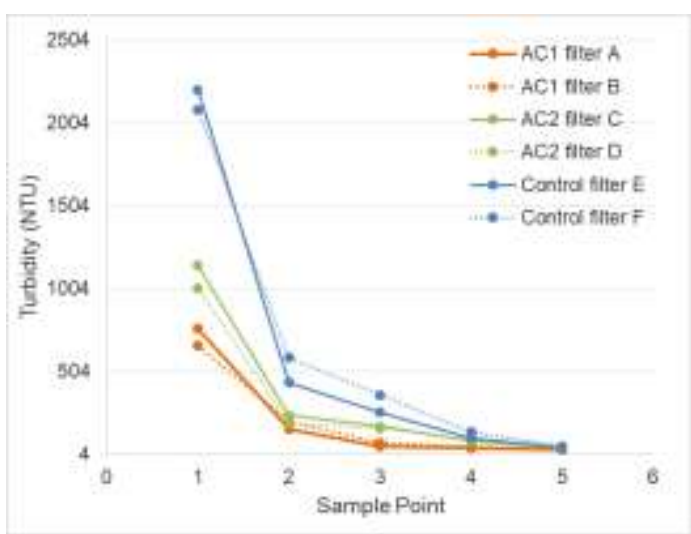

Figure 1: (Filter test part 1) Turbidity results after 24h

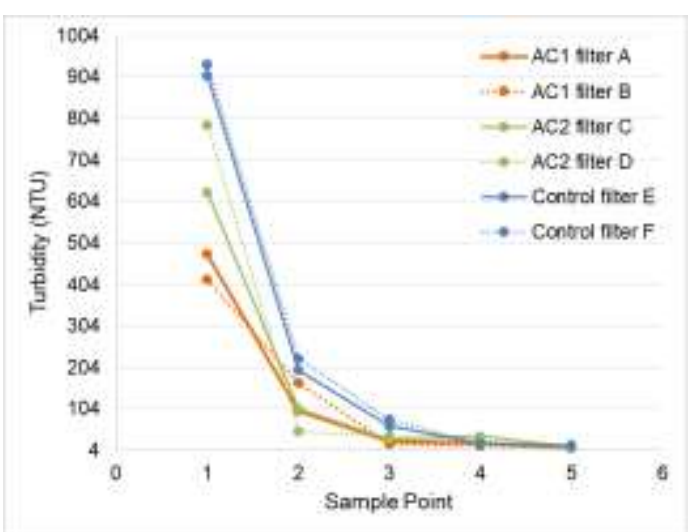

Figure 2: (Filter test part 1) Turbidity results after $48 \mathrm{~h}$

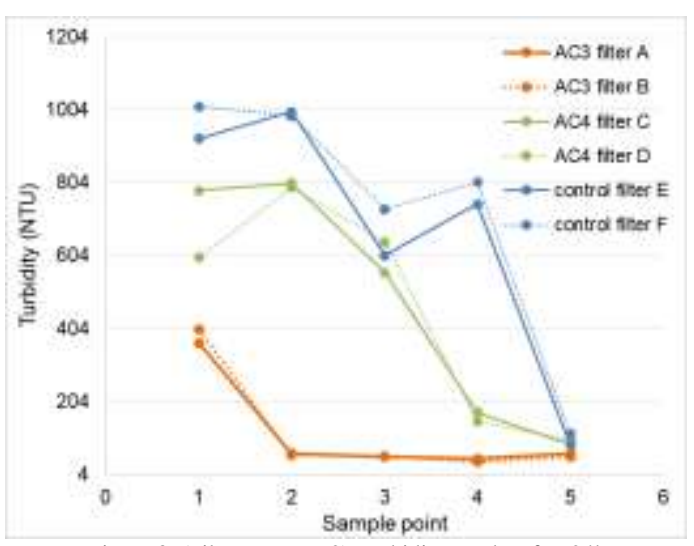

Figure 3: (Filter test part 2) Turbidity results after $24 \mathrm{~h}$

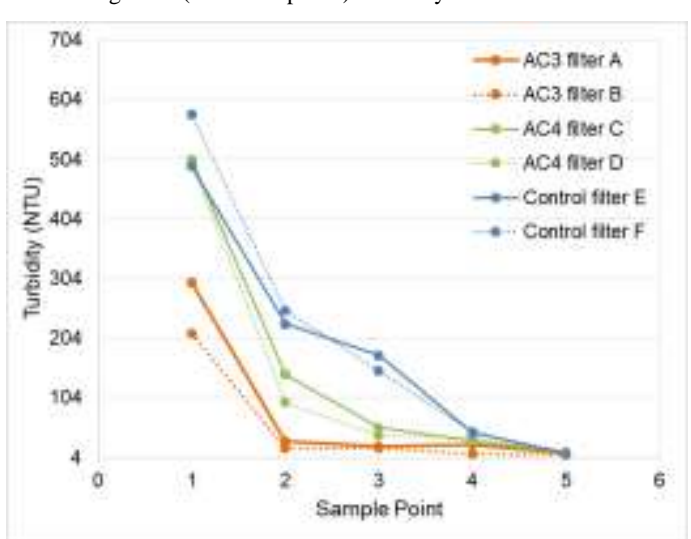

Figure 4: (Filter test part 2) Turbidity results after 48h

Unwashed silica sand and anthracite were used during the test runs. As the flocculated water passes through the granular filter, the filter is rinsed, this explains why the turbidity level are lower after 48 hours compared to the samples taken at 24 hours. The fine activated carbon granules provided additional surface area for particle adhesion. As a result lower filtrate turbidity is observed when any activated carbon is present. The lowest turbidity levels were observed with the addition of activated carbon 1 (AC1), followed by AC3, AC2 and AC4. The highest turbidity levels were observed in the control filters.

\section{B. $p H$}

Wastewater generated by a sorghum brewery has low $\mathrm{pH}$ values. This is mainly a result of the souring stage and the addition of sorghum malt. Sorghum beer is a live fermenting product and when the unsold beer is returned to the brewery and discharged, the effluent $\mathrm{pH}$ value drops. Sodium hydroxide is used at the brewery to maintain a pH level of 7 . Due to this, all samples retrieved from the brewery had a $\mathrm{pH}$ value between 6 and 8 . Coagulation lowered the $\mathrm{pH}$ of the wastewater to a value of approximately 5.5, thereafter the water is added to the filters. The $\mathrm{pH}$ levels of the water sampled from the various filters are shown in Fig. 5 to Fig. 8.
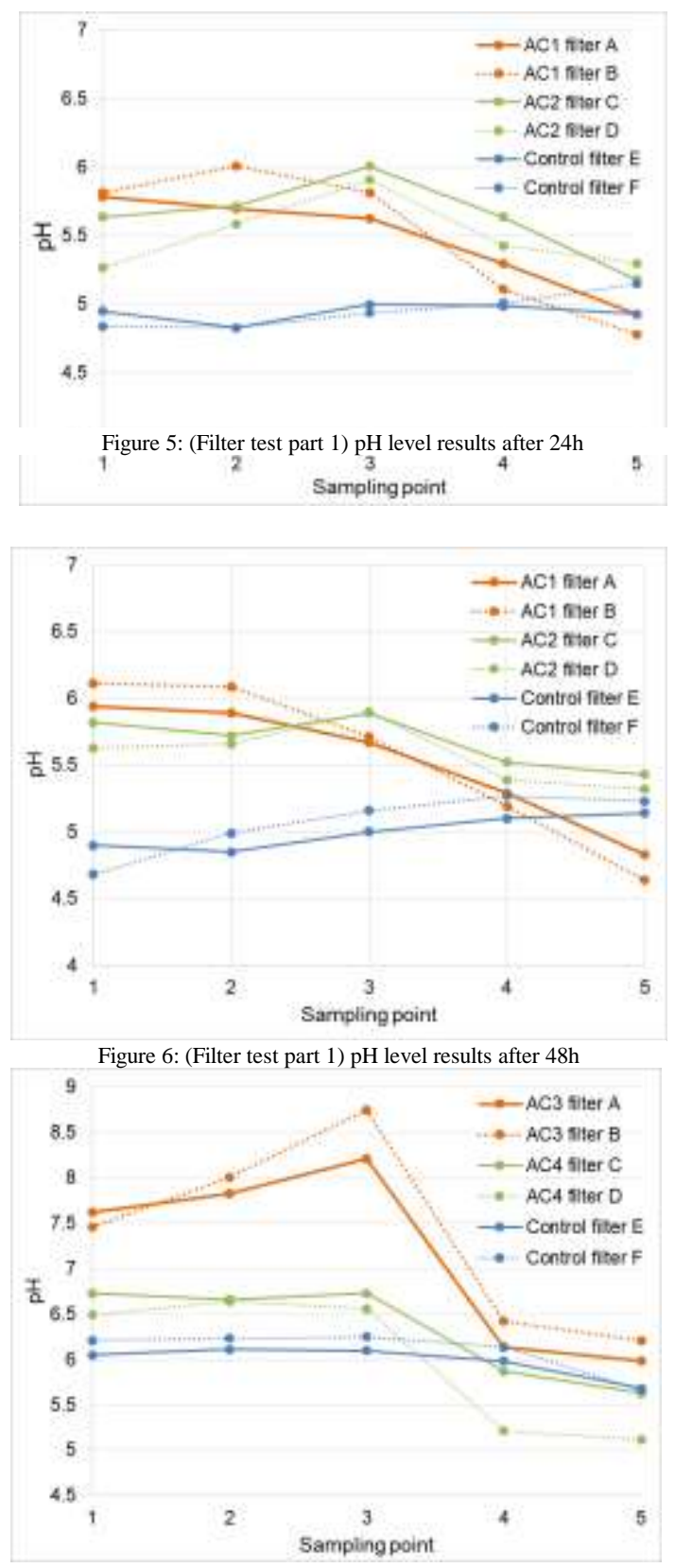

Figure 7: (Filter test part 2) $\mathrm{pH}$ level results after $24 \mathrm{~h}$ 


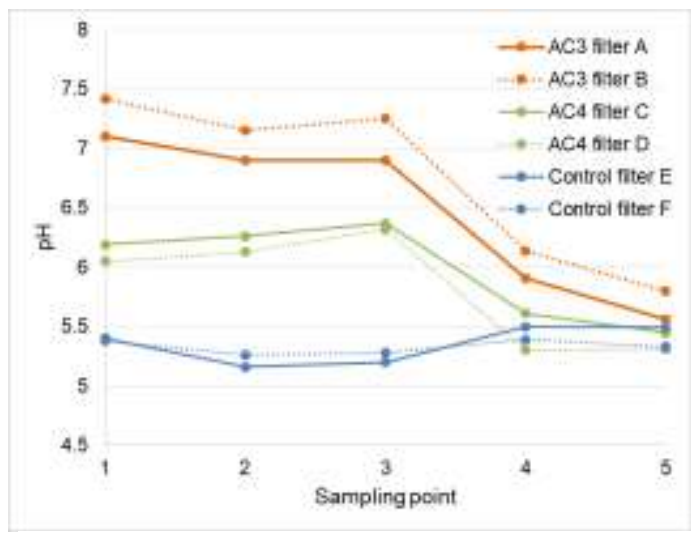

Figure 8: (Filter test part 2) $\mathrm{pH}$ results after $48 \mathrm{~h}$

The presence of activated carbon increases the $\mathrm{pH}$ level of the water. All figures show a relatively constant $\mathrm{pH}$ level for all sampling points in the filters that consist of only sand and anthracite. The introduction on activated carbon (at sampling point 3 ) increases the $\mathrm{pH}$ level of the water, there after the $\mathrm{pH}$ level stabilises again.

The $\mathrm{pH}$ levels are lower after 48 hours when compared to 24 hours, this is to be expected as the anthracite and activated carbon influences the $\mathrm{pH}$ value. More contact time between the water and anthracite (coal) results in sulphuric acid formation therefore lowering $\mathrm{pH}$ level. Most $\mathrm{pH}$ values, with the exception of the control filters are within an allowable range of 5.5 to 9.5 . It can however be noted that additional sodium hydroxide might be needed to increase the $\mathrm{pH}$ level if $\mathrm{pH}$ values drop below 5.5.

\section{Chemical oxygen demand (COD)}

Breweries use the process of fermentation to convert glucose into alcohol. This brewing process is fundamental to the organic chemistry that gives beer its taste, colour and appearance. Brewery waste water contains large amounts of organic contaminants that increase the chemical oxygen demand of the water.

Aerobic microorganisms consume dissolved oxygen in the wastewater. When the organic material content of the water is high, more dissolved oxygen is used by microorganisms [35]. As a result, the water may be deoxygenated and aerobic organisms could die.

The measured COD of part one of the filter tests, after 24 hours and 48 hours is illustrated in Figure 9 and Figure 10. Due to the fact that the water contains a high level of organic substances, some organic reactions may occur in the filters; this may therefore affect the consistency of results.

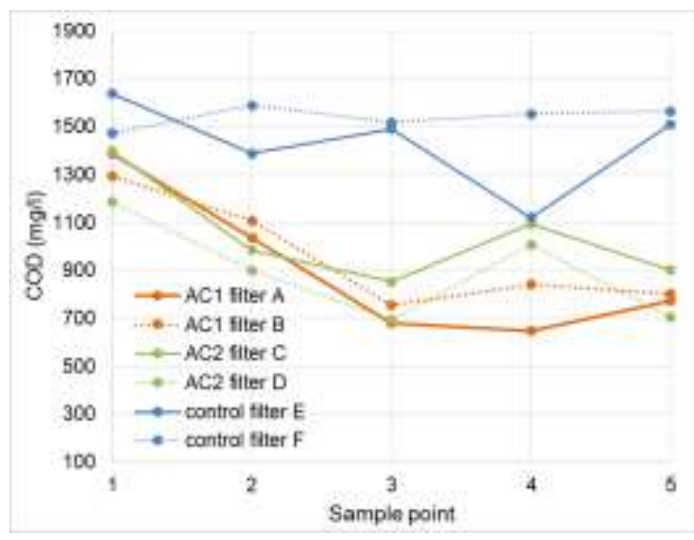

Figure 9: (Filter test part 1) COD of water after $48 \mathrm{~h}$

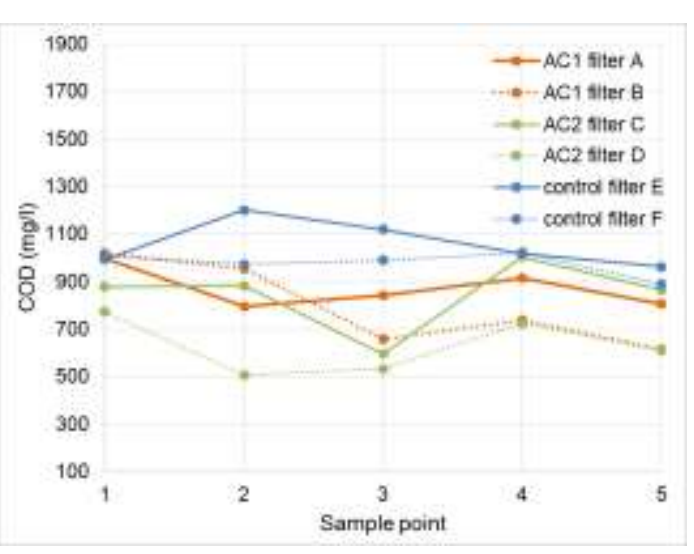

Figure 10: (Filter test part 1) COD of water after $48 \mathrm{~h}$

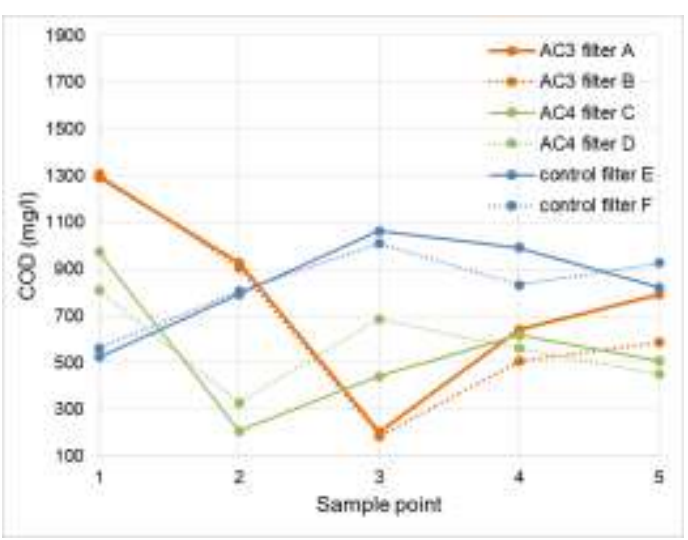

Figure 11: (Filter test part 2) COD of water after $24 \mathrm{~h}$

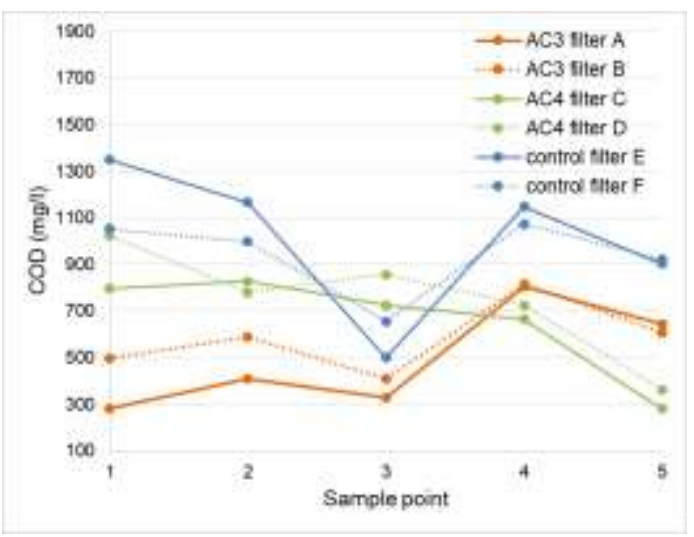

Figure 12: (Filter test part 2) COD of water after $48 \mathrm{~h}$

Part two was conducted in the same manner as part one and the COD measurements are illustrated in Figure 11 and Figure 12. From the data in Figure 9 to Figure 12 it can be seen that the chemical oxygen demand of the water in filters containing activated carbon are lower than the control filters. A prominently lower COD value is achieved at sampling point three. This is to be expected as sampling point three is where the activated carbon is located.

\section{CONCLUSION}

Brewery wastewater remains a concern in the industrial section. Large quantities of pollutants are produced and discharged, due to this fact proper treatment schemes need to be in place to ensure companies comply with government standards. This study created an experimental procedure to study the use of coagulation, flocculation, sedimentation and multimedia filtration for COD removal. From this paper it can 
be seen that activated carbon could contribute greatly to the effectiveness of COD removal in an engineered sand filter system.

\section{ACKNOWLEDGEMENTS}

The authors are grateful to the sponsor from the North-West University and the National Research Foundation in South Africa. Any opinion, findings and conclusions or recommendations expressed in this material are those of the authors and therefore the NRF does not accept any liability in regard thereto.

\section{REFERENCES}

1. Fosso-Kankeu E, Mulaba-Bafubiandi A, Mamba BB, Barnard TG. 2009. Mitigation of $\mathrm{Ca}, \mathrm{Fe}$, and $\mathrm{Mg}$ loads in surface waters around mining areas using indigenous microorganism strains. Journal of Physics and Chemistry of the Earth, Vol 34, pp 825-829. 2. Fosso-Kankeu E, Mulaba-Bafubiandi A, Mamba BB, Marjanovic L, Barnard TG. 2010. A comprehensive study of physical and physiological parameters that affect biosorption of metal pollutants from aqueous solutions. Journal of Physics and Chemistry of the Earth, Vol 35, pp 672-678.

3. Fosso-Kankeu E, Mulaba-Bafubiandi A, Mamba BB, Barnard TG. 2011. Assessing the effectiveness of a biological recovery of nickel from tailings dumps. Journal of Minerals Engineering. Vol 24, pp 470-472.

4. Munyai AH, Fosso-Kankeu E, Waanders F. 2016. Mobility of metals from mine tailings using different types of organic acids: Batch leaching experiment. International Journal of Science and Research. 5: 520-527.

5. Elvis Fosso-Kankeu, Alusani Manyatshe, Frans Waanders. 2017. Mobility potential of metals in acid mine drainage occurring in the Highveld area of Mpumalanga Province in South Africa: Implication of sediments and efflorescent crusts. International Biodeterioration and Biodegradation. 119: 661-670.

6. Fosso-Kankeu E, Mulaba-Bafubiandi A, Mamba BB, Barnard TG. 2009. Indigenous microorganism strains as bio-extractants of $\mathrm{Ca}, \mathrm{Fe}$ and $\mathrm{Mg}$ from metallurgical and mine drainages. The Southern African Institute of Mining and Metallurgy, Hydrometallurgy Conference 2009. Symposium Series S54, pp 93-100.

7. F. Waanders, M. Nel, E. Fosso-Kankeu. 2014. Adsorption potential of bentonite clay and attapulgite applied for the desalination of sea water. $6^{\text {th }}$ International Conference on Green Technology, Renewable Energy and Environmental Engineering (ICGTREEE'2014). 27-28 November 2014, Cape Town-South Africa. Editors: Muzenda E. and Sandhu S. ISBN: 978-93-84468-08-8. Pp 275-279.

8. Fosso-Kankeu E, Waanders F, Reitz M. 2014. Selective adsorption of heavy and light metals by natural zeolites. $6^{\text {th }}$ International Conference on Green Technology, Renewable Energy and Environmental Engineering (ICGTREEE'2014). 27-28 November 2014, Cape Town-South Africa. (Award Winning Paper). Editors: Muzenda E. and Sandhu S. ISBN: 978-93-84468-08-8. Pp 271-274.

9. Elvis Fosso-Kankeu, Frans B. Waanders, and Ashley H. Munyai. 2015. Susceptibility of Metals Release from Tailings Dumps Located In the Krugersdorp Area. $7^{\text {th }}$ International Conference on Latest Trends in Engineering and Technology (ICLTET' 2015), November 26-27, 2015 Irene, Pretoria (South Africa). Editors: E. Muzenda and T Yingthawornsuk. ISBN: 978-93-84422-58-5.
10. Elvis Fosso-Kankeu, Elxzente Maloy, and Frans Waanders. 2015. Preparation of Ethyl Acrylate - Guar Gum Copolymer for the Mitigation of Water Hardness. $7^{\text {th }}$ International Conference on Latest Trends in Engineering and Technology (ICLTET' 2015), November 26-27, 2015 Irene, Pretoria (South Africa). Editors: E. Muzenda and T Yingthawornsuk. ISBN: 978-93-84422-58-5.

11. Steffen, R., Kirsten \& Commission, S. A. W. R. 1989. Water and Waste-water Management in the Sorghum, Malt and Beer Industries: Prepared for the Water Research Commission, The Commission.

12. Lyumugabe, F., Gros, J., Nzungize, J., Bajyana, E. \& Thonart, P. 2012a. Characteristics of African traditional beers brewed with sorghum malt: a review. BASE [En ligne], 16, 509-530.

13. van Niekerk, A. M. 2000. TECHNOLOGICAL PERSPECTIVES ON THE NEW SOUTH AFRICAN EFFLUENT (WASTE) DISCHARGE STANDARDS. WISA 2000 Biennial Conference, 2000 Sun City, South Africa.

14. Thomas, K.R. \& Rahman, P. K. S. M. 2006. Brewery wastes. Strategies for sustainability. A review. Aspects of Applied Biology, 8, 147-153.

15. Null, S.E., Mouzon, N.R. \& Elmore, L. R. 2017. Dissolved oxygen, stream temperature, and fish habitat response to environmental water purchases. Journal of Environmental Management, 197, 559-570.

16. Garg, V., Senthil Kumar, A., Aggarwal, S.P., Kumar, V., Dhote, P.R., Thakur, P.K., Nikam, B.R., Sambare, R.S., Siddiqui, A., Muduli, P.R. \& Rastogi, G. 2017. Spectral similarity approach for mapping turbidity of an inland waterbody. Journal of Hydrology, 550, 527-537.

17. E. Fosso-Kankeu, F. Waanders, A.F. Mulaba-Bafubiandi, A.K. Mishra. 2016. Flocculation performances of polymers and nanomaterials for the treatment of industrial wastewaters. In A.K Mishra (ed). 2016. Smart

Materials for Waste Water Applications. Wiley Scrivener. ISBN: 9781119041184. Pp 213 - 235.

18. Fosso-Kankeu E, Waanders F, Reitz M. 2014. Selective adsorption of heavy and light metals by natural zeolites. $6^{\text {th }}$ International Conference on Green Technology, Renewable Energy and Environmental Engineering (ICGTREEE'2014). 27-28 November 2014, Cape Town-South Africa. (Award Winning Paper). Editors: Muzenda E. and Sandhu S. ISBN: 978-93-84468-08-8. Pp 271-274.

19. Elvis Fosso-Kankeu, Frans Waanders, Corinne Fraser. 2014. Bentonite clay adsorption affinity for anionic and cationic dyes. $6^{\text {th }}$ International Conference on Green Technology, Renewable Energy and Environmental Engineering (ICGTREEE'2014). 27-28 November 2014, Cape Town-South Africa. Editors: Muzenda E. and Sandhu S. ISBN: 978-93-84468-08-8. Pp 257-260. Pp 257-260. 20. Fosso-Kankeu Elvis, Van der Berg Charl M., Frans B. Waanders. 2014. Physico-chemical activation of South African bentonite clay and impact on metal adsorption capacity. $6^{\text {th }}$ International Conference on Green Technology, Renewable Energy and Environmental Engineering (ICGTREEE'2014). 27-28 November 2014, Cape Town-South Africa. Editors: Muzenda E. and Sandhu S. ISBN: 978-93-84468-08-8. Pp 247-252.

21. Elvis Fosso-Kankeu; Oupa Ntwampe; Frans Waanders, and Alicea Webster. 2015. The Performance of Polyaluminium Chloride and Bentonite clay Coagulant in the Removal of Cationic and Anionic Dyes. $7^{\text {th }}$ International Conference on Latest Trends in Engineering and Technology (ICLTET' 2015), November 26-27, 2015 Irene, Pretoria (South Africa). Editors: E. Muzenda and T Yingthawornsuk. ISBN: 978-93-84422-58-5.

22. Noh, Y.D., Komarneni, S., Cannon, F.S., Brown, N.R. \& Katsuki, H. 2016. Anthracite briquettes with plant byproducts as an ecofriendly fuel for foundries. Fuel, 175, 210-216. 
23. Kuosa, M., Ekberg, B., Tanttu, 1., Jauhiainen, T. \& Häkkinen, A. 2017. Performance comparison of anthracite filter media of different origin in the removal of organic traces from copper electrolyte. International Journal of Mineral Processing, 163, 24-34.

24. Ebeling, J.M., Sibrell, P.1., Ogden, S.R. \& Summerfelt, S. T. 2003. Evaluation of chemical coagulation-flocculation aids for the removal of suspended solids and phosphorus from intensive recirculating aquaculture effluent discharge. Aquacultural Engineering, 29, 23-42.

25. Elvis Fosso-Kankeu, Alusani Manyatshe, Divan van der Berg, Nico Lemmer, Frans Waanders, and Tutu Hlanganani. 2015. Contaminants in Sediments across the Mooi and Vaal Rivers Network in The Vicinity of Potchefstroom. $7^{\text {th }}$ International Conference on Latest Trends in Engineering and Technology (ICLTET' 2015), November 26-27, 2015 Irene, Pretoria (South Africa). Editors: E. Muzenda and T Yingthawornsuk. ISBN: 978-93-84422-58-5.

26. Elvis Fosso-Kankeu, Frans B. Waanders, and Ashley H. Munyai. 2015. Susceptibility of Metals Release from Tailings Dumps Located In the Krugersdorp Area. $7^{\text {th }}$ International Conference on Latest Trends in Engineering and Technology (ICLTET' 2015), November 26-27, 2015 Irene, Pretoria (South Africa). Editors: E. Muzenda and T Yingthawornsuk. ISBN: 978-93-84422-58-5.

27. Elvis Fosso-Kankeu, Divan P. Van der Berg, Frans Waanders, Alusani Manyatshe, Nico Lemmer, and H. Tutu. 2015. Mapping of surface water quality in the vicinity of Potchefstroom based on mining pollutants. $7^{\text {th }}$ International Conference on Latest Trends in Engineering and Technology (ICLTET' 2015), November 26-27, 2015 Irene, Pretoria (South Africa). Editors: E. Muzenda and T Yingthawornsuk. ISBN: 978-93-84422-58-5.

28. Alusani Manyatshe, Elvis Fosso-Kankeu, Divan van der Berg, Nico Lemmer, Frans Waanders, Hlanganani Tutu. 2017. Metal retention potential of sediment and water quality in the Mooi River, South Africa. Desalination and Water Treatment. doi: 10.5004/dwt2017.20222.

29. A. Manyatshe, E. Fosso-Kankeu, D. van der Berg, N. Lemmer, F. Waanders, H. Tutu. 2017. Dispersion of inorganic contaminants in surface water in the vicinity of Potchefstroom. Physics and Chemistry of the Earth. 100: 86-93.

30. Fosso-Kankeu E, Waanders F, Van Niekerk D, Rogers D, Gericke D. 2016. Treatment of raw and processed waters from coal power plant using $\mathrm{PACl}$ supplemented with cationic organic polymer and bentonite. International Conference on Advances in Science, Engineering, Technology and Natural Resources (ICASETNR-16) Nov. 24-25, 2016, Parys - South Africa. ISBN: 978-93-84468-79-8.

31. Fosso-Kankeu E, Waanders F, Swiegers R, Ntwampe IO, Rogers D, Gericke G. 2016. Impact of the physico-chemical properties of water on the flocculation performance of lime, clay and other polymers. International Conference on Advances in Science, Engineering, Technology and Natural Resources (ICASETNR-16) Nov. 24-25, 2016, Parys - South Africa. ISBN: 978-93-84468-79-8. 32. Ntwampe IO, Waanders FB, Fosso-Kankeu E and Bunt JR. 2015. Turbidity removal efficiency of clay and a synthetic af-PFCl Polymer of Magnesium Hydroxide in AMD Treatment. International Scientific Research Journal. 4: 38-55.

33. E. Fosso-Kankeu, H. Mittal, F. Waanders, I.O. Ntwampe, S.S. Ray. 2016. Preparation and characterization of gum karaya hydrogel nanocomposite flocculant for metal ions removal from mine effluents International Journal of Environmental Science and Technology. 13: 711-724.

34. E Fosso-Kankeu, A Webster, IO Ntwampe, FB Waanders. 2016. Coagulation/flocculation potential of polyaluminium chloride and bentonite clay tested in the removal of methyl red and crystal violet. Arabian Journal for Science and Engineering. DOI 10.1007/s13369-016-2244-x.

35. Hough, J. S. 1991. The Biotechnology of Malting and Brewing, Cambridge University Press.

The corresponding author is currently an Associate Professor in the School of Chemical and Minerals Engineering at the North-West University (Potchefstroom). He is an NRF rated researcher who has published journal articles, book chapters and book.

Prof Elvis Fosso-Kankeu has been the recipient of several merit awards. 